\title{
TNF- $\alpha$ inhibits xenograft tumor formation by A549 lung cancer cells in nude mice via the HIF-1 $\alpha$ /VASP signaling pathway
}

\author{
WEN LIU $^{1,2^{*}}$, XIANG CHEN $^{1 *}$, YANQI HE $^{1 *}$, YIHAO TIAN $^{3}$, LIU XU $^{1}$, YANBIN MA $^{1}$, \\ PENGCHAO HU ${ }^{1}, \mathrm{KE} \mathrm{SU}^{2}$, ZHENYU LUO $^{2}$, LEI WEI ${ }^{1}$ and JINGWEI ZHANG ${ }^{4}$ \\ ${ }^{1}$ Hubei Provincial Key Laboratory of Developmentally Originated Disease, Department of Pathology and Pathophysiology, \\ School of Basic Medical Sciences, Wuhan University, Wuhan, Hubei 430071; ${ }^{2}$ Renmin Hospital of Wuhan University, \\ The First College of Clinical Medicine of Wuhan University, Wuhan, Hubei 430060; \\ ${ }^{3}$ Department of Human Anatomy and Histology and Embryology, School of Basic Medical Sciences, Wuhan University; \\ ${ }^{4}$ Department of Breast and Thyroid Surgery, Zhongnan Hospital of Wuhan University, Hubei Key Laboratory \\ of Tumor Biological Behaviors, Hubei Cancer Clinical Study Center, Wuhan, Hubei 430071, P.R. China
}

Received March 17, 2018; Accepted January 24, 2019

DOI: $10.3892 / o r .2019 .7026$

\begin{abstract}
Lung cancer is the leading cause of cancer-associated mortality worldwide. Tumor necrosis factor $\alpha$ (TNF- $\alpha)$ is an important cytokine in the tumor microenvironment that serves a function in the balance of cell survival and cell death pathways. Our previous studies indicated that hypoxia-inducible factor $1 \alpha$ (HIF-1 $\alpha$ ) acts downstream of TNF- $\alpha$ in MCF-7 luminal breast cancer cells. However, whether vasodilator-stimulated phosphoprotein (VASP) is implicated in the direct regulation of HIF-1 $\alpha$ in response to TNF- $\alpha$ in lung cancer remains unknown. In vitro studies were performed using A549 and H226 lung carcinoma cells and in vivo studies of tumor xenograft models were performed to investigate the effects of TNF- $\alpha$. The results demonstrated that TNF- $\alpha$ decreased VASP expression by upregulating the expression of HIF-1 $\alpha$ to inhibit A549 cell proliferation and adhesion. Inhibition of transplanted tumor growth was associated with downregulation of VASP expression in nude mice. Bioinformatics analysis indicated that expression levels of VASP or HIF-1 $\alpha$ lead to differential outcomes of overall
\end{abstract}

Correspondence to: Professor Jingwei Zhang, Department of Breast and Thyroid Surgery, Zhongnan Hospital of Wuhan University, Hubei Key Laboratory of Tumor Biological Behaviors, Hubei Cancer Clinical Study Center, 185 Donghu Road, Wuhan, Hubei 430071, P.R. China

E-mail: zjwzhang68@hotmail.com

${ }^{*}$ Contributed equally

Abbreviations: TNF- $\alpha$, tumor necrosis factor $\alpha$; HIF-1 $\alpha$, hypoxiainducible factor $1 \alpha$; VASP, vasodilator-stimulated phosphoprotein

Key words: vasodilator-stimulated phosphoprotein, tumor necrosis factor $\alpha$, hypoxia-inducible factor $1 \alpha$, A549, xenograft model, antitumor survival in lung carcinoma. These results suggest that the HIF-1 $\alpha$ /VASP signaling pathway serves an important function in the regulation of TNF- $\alpha$-induced suppression of A549 cell proliferation and xenograft growth. This may improve our understanding of the antitumor effect of TNF- $\alpha$.

\section{Introduction}

Lung cancer remains the leading cause of cancer-associated mortality worldwide, and adenocarcinoma is the most common histological type, accounting for almost half of these mortalities (1). Environmental and genetic factors favoring lung cancer initiation and progression through clinical, pathological and molecular mechanisms interact in a complex and poorly understood fashion (2,3). Owing to tumor heterogeneity, molecularly targeted therapies have effectively improved treatment for patients exhibiting mutated epidermal growth factor receptor or translocated anaplastic lymphoma kinase genes (4). However, patients without identifiable target genes are treated with conventional chemotherapy (5). Therefore, it is necessary to investigate the underlying molecular mechanisms of lung cancer to develop more efficient targeted therapies.

Tumor necrosis factor $\alpha(\mathrm{TNF}-\alpha)$ is a pleiotropic proinflammatory cytokine involved in the regulation of various physiological and pathological signaling pathways, including inflammation, differentiation, proliferation and apoptosis induction $(6,7)$. In the tumor microenvironment, TNF- $\alpha$ accelerates multistep cancer progression by promoting proliferation, migration and adhesion of cancer cells, and genesis of neo-tumor vessels $(8,9)$. However, TNF- $\alpha$ has also been demonstrated to be an antitumor cytokine exhibiting cancer cell toxicity in vitro and in vivo, by directly inducing apoptosis and necrosis of cancer cells, increasing antitumor immunity and impairing tumor blood vessel formation (7,10-12). The dual and opposing functions of TNF- $\alpha$ in cancer progression and regression are likely to occur in response to various routes and dosages of administration of TNF- $\alpha$, which may activate different signal transduction pathways, a mechanism which requires further elucidation (13-15). 
Hypoxia-inducible factor $1 \alpha(\mathrm{HIF}-1 \alpha)$ is an oxygen-sensitive subunit of the heterodimeric transcription factor HIF-1, associated with the constitutively expressed subunit HIF-1 $\beta$ via targeting the hypoxia-responsive element, causing downstream gene promoters to activate transcription in the nucleus $(16,17)$. It has been identified that HIF-1 $\alpha$, characterized by high expression during hypoxia and rapid degradation in normoxia, is regulated by the tumor suppressor von Hippel-Lindau protein (18). HIF-1 $\alpha$ functions as a tumor promoter at the crossroads of inflammation and cancer, and is widely activated in various types of human tumor tissue $(19,20)$. Evidence indicates that high nuclear expression levels of HIF-1 $\alpha$ in cancer tissues are directly correlated with decrease survival times in lymph node-positive patients (21). In contrast, HIF-1 $\alpha$ has been demonstrated to regulate tumor metabolism as a tumor suppressor in breast cancer cells, but not in cancer-associated fibroblasts (22). Further studies revealed that HIF-1 $\alpha$ expression is significantly negatively correlated with the anti-apoptotic protein B-cell lymphoma 2 (Bcl-2), and significantly positively correlated with the pro-apoptotic factor Bcl-2-associated X protein in lung cancer (23). Currently, the function of HIF- $1 \alpha$ remains controversial and it has been reported to differ with various tumor and stromal cell types (24).

The vasodilator-stimulated phosphoprotein $(V A S P)$ gene is located on human chromosome 19q13.2-13.3 (25). As a member of the Ena/VASP protein family, VASP is an actin-associated protein, which promotes actin filament elongation by assembling actin monomers to the minus end, and contributes to cytoskeleton rearrangement-based cellular protrusion formation, cell adhesion and movement (26-28). Galler et al (29) identified that VASP regulates cytoskeletal stability as well as focal adhesion in VASP-knockout mice. VASP has been investigated with respect to its ability to alter the biology of tumor cells regarding the processes of proliferation, migration and invasion (30). Knockdown of VASP has been revealed to inhibit the neoplastic transformation of NIH3T3 fibroblasts in nude mice (31). Likewise, we demonstrated previously that VASP is overexpressed in human primary breast cancer and is involved in the antitumor activity of TNF- $\alpha$, depending on HIF-1 $\alpha$, in the luminal breast cancer cell line MCF-7 $(32,33)$. The aim of the present study was to understand the function of TNF- $\alpha / \mathrm{HIF}-1 \alpha / \mathrm{VASP}$ signaling in vitro and in vivo, and also to investigate a potential therapeutic mechanism for the treatment of lung cancer.

\section{Materials and methods}

Plasmid constructs. Human VASP cDNA (pEGFP-C1-VASP) or HIF1A cDNA (pEGFP-C1-HIF-1 $\alpha$ ) was cloned into the pEGFP-C1 vector (Clontech Laboratories, Inc., Mountainview, CA, USA). The 5'-flanking region of the putative VASP promoter was amplified from human genomic DNA using the polymerase chain reaction and cloned into the pGL3-Basic vector (Promega Corporation, Madison, WI, USA) to construct the VASP reporter plasmids. pGL3-2.1K reporter plasmids contained the HIF-1 $\alpha$-binding site (HBS) which spanned the VASP promoter from -1921 to +230 bp. pGL3-362 lacked the HBS which spanned the sequence from -132 to +230 bp. All constructs were confirmed by sequencing.
Cell culture and transfection. The human lung adenocarcinoma cell line A549 was obtained from the China Center for Type Culture Collection, Wuhan University (Wuhan, China). The human squamous lung carcinoma cell line H226 was obtained from the Cell Bank of the Type Culture Collection of the Chinese Academy of Sciences (Shanghai, China). Cells were cultured in RPMI-1640 medium (HyClone; GE Healthcare, Logan, UT, USA) supplemented with $10 \%$ fetal bovine serum (HyClone; GE Healthcare), $1 \%$ penicillin $\mathrm{G}$ and $1 \%$ streptomycin. The cells were maintained at $37^{\circ} \mathrm{C}$ in a humidified atmosphere containing $5 \% \mathrm{CO}_{2}$. Transient transfection was performed using TurboFect Transfection Reagent (Roche Diagnostics, Basel, Switzerland).

Cell viability and adhesion assay. An MTT assay (Sigma-Aldrich; Merck KGaA, Darmstadt, Germany) was used to determine cell viability. Cells were seeded in 96-well plates at a density of $1 \times 10^{5}$ cells $/ \mathrm{ml}(100 \mu \mathrm{l} /$ well $)$. Cells in each experimental group were treated with TNF- $\alpha$ (Invitrogen; Thermo Fisher Scientific, Inc., Waltham, MA, USA) at concentrations of $0,7.5,30,120$ and $240 \mathrm{ng} / \mathrm{ml}$, and treated with the equivalent volume of nutrient medium in the control group. Laminin (7,200 $\mu \mathrm{g} / \mathrm{ml}$; BD Biosciences, Franklin Lakes, NJ, USA) had been previously coated onto 96-well plates for the determination of the adhesive ability of cancer cells. The plates were incubated at $37^{\circ} \mathrm{C}$ for $2 \mathrm{~h}$, and then washed with PBS to remove all non-adherent cells. MTT was added to each well $(20 \mu \mathrm{l} ; 5 \mathrm{mg} / \mathrm{ml}$ in PBS), and the plates were incubated at $37^{\circ} \mathrm{C}$ for $4 \mathrm{~h}$. A total of $200 \mu \mathrm{l}$ dimethyl sulfoxide was added to dissolve the formazan crystals that formed. Spectrophotometric absorbance was measured at a wavelength of $570 \mathrm{~nm}$ using a microplate reader to determine the optical density (OD). The viability of cells was calculated by comparison with the vehicle control-treated cells, which were arbitrarily assigned a viability of $100 \%$. The percentage of adhesion was calculated according to the following formula: Percentage of adhesion $=\left(\mathrm{OD}_{570}\right.$ of treated cells $/ \mathrm{OD}_{570}$ of untreated cells) x $100 \%$. The experiments were performed in triplicate, independently.

RNA interference. Short hairpin RNA (shRNA) duplexes were designed against VASP (GenBank accession no. BC038224) with the sequence 5'-TGCTGTAAAGCATCACAGTGGCCC GGGTTTTGGCCACTGACTGACCCGGGCCAGTGATGC TTTA-3' and were inserted into the pcDNA ${ }^{\mathrm{TM}} 6.2-\mathrm{GW} / \mathrm{EmGFP}$ vector (Invitrogen; Thermo Fisher Scientific, Inc.) to generate pcDNA $^{\mathrm{TM}}$ 6.2-GW/EmGFP-miR-VASP. HIF-1 $\alpha$ short interfering RNA (siRNA) (31) duplexes were designed against HIF1A (GenBank accession no. NM_001530) with the sequence 5'-CUGAUGACCAGCAACUUGAdTdT-3', and synthesized by Shanghai GenePharma Co., Ltd. (Shanghai, China). A scrambled siRNA with the sequence 5'-AGU UCAACGACCAGUAGUCdTdT-3' and a scrambled shRNA (Invitrogen; Thermo Fisher Scientific, Inc.) were used as negative controls.

Luciferase assay. Cells were seeded in 24-well plates at a density of $5 \times 10^{5}$ cells $/ \mathrm{ml}(300 \mu \mathrm{l} /$ well $)$ and co-transfected with $100 \mathrm{ng}$ luciferase reporter construct, $20 \mathrm{ng}$ Renilla luciferase pRL-TK reporter and $400 \mathrm{ng}$ pEGFP-C1-HIF-1 $\alpha$ the next 
day. After $24 \mathrm{~h}$, the cells were harvested and the luciferase activity was determined using a Dual-Luciferase Reporter assay system (Promega Corporation) with a GloMax 2020 Luminometer (Promega Corporation), according to the manufacturer's protocol. Finally, the results were normalized to Renilla luciferase activity. Each experiment was performed in triplicate wells at least 3 times.

Isolation of $R N A$ and reverse transcription-quantitative PCR (RT-qPCR) analysis. Total RNA was isolated from cells using TRIzol ${ }^{\circledR}$ reagent (Invitrogen; Thermo Fisher Scientific, Inc.). The cDNA was synthesized with a RevertAid FirstStrand cDNA Synthesis kit (Fermentas; Thermo Fisher Scientific, Inc.). The resulting cDNA was analyzed using qPCR and a 7500 Fast Real-Time PCR system. The PCR primers used were as follows: VASP, forward, 5'-AAAGTCAGCAAGCAG GAGGA-3', and reverse, 5'-ATTCATCCTTGGGGGTTT TC-3'; HIF-1 $\alpha$, forward, 5'-GAAAGCGCAAGTCCTCAA AG-3' and reverse, 5'-TGGGTAGGAGATGGAGATGC-3'; and GAPDH, forward, 5'-CCTTCCTGACAGCCAGTGTG-3' and reverse, 5'-CAGAATGGAAATACTGGAGCAAG-3'. All PCRs were performed 3 times each with 3 or more replicates. Relative mRNA expression was calculated using the $2^{-\Delta \Delta \mathrm{Cq}}$ method (34). HIF-1 $\alpha$ thermocycling conditions consisted of 40 cycles of $94^{\circ} \mathrm{C}$ for $10 \mathrm{sec}, 54^{\circ} \mathrm{C}$ for $10 \mathrm{sec}$ and $72^{\circ} \mathrm{C}$ for $10 \mathrm{sec}$. VASP thermocycling conditions consisted of 40 cycles of $94^{\circ} \mathrm{C}$ for $40 \mathrm{sec}, 58^{\circ} \mathrm{C}$ for $10 \mathrm{sec}$ and $72^{\circ} \mathrm{C}$ for $10 \mathrm{sec}$.

Western blotting. Cells were harvested and then lysed in a modified radioimmunoprecipitation assay buffer. The lysates were centrifuged at $13,400 \mathrm{x} \mathrm{g}$, for $15 \mathrm{~min}$ at $4^{\circ} \mathrm{C}$. Bicinchoninic Acid Protein assay kit (Pierce; Thermo Fisher Scientific, Inc.) was used to detect protein concentration. Equal amounts of total protein $(10 \mu \mathrm{g})$ were separated by SDS-PAGE (10\% gel) and transferred onto polyvinylidene difluoride membranes (EMD Millipore, Billerica, MA, USA). Following blocking in 5\% non-fat milk in PBS for $2 \mathrm{~h}$ at room temperature, the membranes were incubated overnight at $4^{\circ} \mathrm{C}$ with primary antibodies against the following: Rabbit VASP (1:1,000; cat. no. 13472-1-AP; ProteinTech Group Inc., Chicago, IL, USA), rabbit HIF-1 $\alpha$ (1:1,000; cat. no. ab82832; Abcam, Cambridge, UK) and mouse GAPDH $(1: 2,000$; cat. no. sc-69778; Santa Cruz Biotechnology, Inc., Dallas, TX, USA). The membranes were washed and then incubated with horseradish peroxidase-labeled secondary antibody, either goat anti-rabbit IgG (1:5,000; cat. no. sc-2004; Santa Cruz Biotechnology, Inc.) or goat anti-mouse IgG (1:5,000; cat. no. sc-2005; Santa Cruz Biotechnology, Inc.) for $1 \mathrm{~h}$ at room temperature. The blots were visualized with Enhanced Chemiluminescence reagents (Pierce; Thermo Fisher Scientific, Inc.). All experiments were performed 3 times.

Tumor xenograft model. Animal experiments were carried out according to the guidelines of the Laboratory Animal Center of Wuhan University. Male BALB/c athymic nude mice, 6 weeks in age, were purchased from the Model Animal Research Center of Wuhan University. A549 cells were injected subcutaneously ( $1 \times 10^{7}$ tumor cells in $\left.0.1 \mathrm{ml} \mathrm{PBS}\right)$ into the right-lower flank of the carrier mice. Mice were divided randomly into two groups (6 animals/group) when the tumor volume reached 50-60 mm $\mathrm{mm}^{3}$ TNF- $\alpha$ was delivered at $54 \mu \mathrm{g} / \mathrm{kg}$, intraperitoneally, once every 3 days for 15 days ( 5 times in total), and the control group was injected with normal saline. The weight of the mice and their tumor volumes were measured every 3 days. The tumor volumes were measured with Vernier calipers and calculated using the following formula: $\mathrm{LxW}^{2} / 2$, where $\mathrm{L}$ is the larger and $\mathrm{W}$ is the smaller of the 2 dimensions. The relative tumor volume (RTV) was calculated as follows: (mean tumor volume during treatment)/(mean tumor volume prior to treatment). The animal experiments were approved by the Experimental Ethics Committee in Basic Medical Sciences, Wuhan University (Wuhan, China). At $24 \mathrm{~h}$ after the final injection, mice were sacrificed by anesthesia followed by cervical dislocation. Mice were also sacrificed if any single tumor reached a diameter of $10 \mathrm{~mm}$ or if any animal was adjudged to be in poor health and did not eat. No multiple tumors were observed in any individual mouse.

Hematoxylin and eosin $(H \& E)$ staining, immunohistochemistry and immunohistochemistry. The transplanted tumors were separated from the surrounding muscles and dermis, excised, weighed and then fixed in $4 \%$ paraformaldehyde for $\mathrm{H} \& \mathrm{E}$ staining and immunohistochemistry (HIF-1 $\alpha$, VASP and caspase-3) or prefixed in $2.5 \%$ glutaraldehyde for transmission electron microscopy (Hitachi, Ltd., Tokyo, Japan) for examination.

The tumor sections were collected and fixed in $4 \%$ paraformaldehyde. Paraffin-embedded tissue sections $(5 \mathrm{~mm})$ were stained with H\&E, according to standard techniques (35). Images were captured using a Nikon Eclipse Ci light microscope (Nikon Instruments, Inc., Tokyo, Japan).

The lung tumor was cut into three 1-mm sections, and fixed by immersion in $4 \%$ prechilled glutaraldehyde. Subsequently, it was followed by post-fixation with $1 \%$ osmium tetroxide. Samples were dehydrated in a graded ethanol series, embedded in Epon 812 (SPI Supplies/Structure Probe, Inc., West Chester, PA, USA). The sections were examined under by transmission electron microscopy (35).

Slides were deparaffinized, dehydrated through a graded alcohol series and rinsed with distilled water. Antigen retrieval was carried out by boiling slides in $1 \mathrm{mM}$ sodium citrate buffer (pH 6.0) followed by $20 \mathrm{~min}$ at a sub-boiling temperature and incubating with $3 \% \mathrm{H}_{2} \mathrm{O}_{2}$ for $12 \mathrm{~min}$ at room temperature to block endogenous peroxidase. Next, the sections were washed with PBS ( $\mathrm{pH} 7.5)$, and incubated in protein blocking solution [0.5\% normal goat serum (Thermo Fisher Scientific, Inc.) in PBS] for $30 \mathrm{~min}$. The sections were then incubated with anti-VASP (1:200), anti-HIF-1 $\alpha$ (1:200) and anti-rabbit cleaved caspase-3 (1:200; cat. no. 9661; Cell Signaling Technology, Inc., Danvers, MA, USA) primary antibody in a humidified chamber at $37^{\circ} \mathrm{C}$ for $2 \mathrm{~h}$, rinsed with PBS 3 times, and incubated with rhodamine red X-conjugated anti-immunoglobulin G secondary antibody (1:200; cat. no. 109-297-008; Jackson ImmunoResearch Laboratories, Inc., West Grove, PA, USA) at room temperature for $1 \mathrm{~h}$. 3,3'-Diaminobenzidine (OriGene Technologies, Inc., Beijing, China) was used to stain slides for $2 \mathrm{~min}$ at room temperature and the coloring reaction was stopped using distilled water, counterstained with Gill's hematoxylin for $1 \mathrm{~min}$ at room temperature (Sigma; Merck KGaA) and observed under a BX53 light microscope 
(Olympus Corporation, Tokyo, Japan). The mean densities of the sections were analyzed using Image-Pro Plus 4.5 software (National Institutes of Health, Bethesda, MD, USA).

Online databases. Data from the Kaplan the patients with Lung cancer were divided into a low expression level group and a high expression level group, according to the median VASP or HIF-1 $\alpha$ mRNA expression levels, using KM-Plotter (kmplot. com/analysis/index.php? $\mathrm{p}=$ service \&cancer=lung). VASP Affy ID, 202205_at; HIF-1 $\alpha$ Affy ID, 200989_at. The restriction of histology was adenocarcinoma and squamous cell carcinoma.

Statistical analysis. Results are presented as the mean \pm standard error of the mean. Statistical significance between groups was tested using one-way analysis of variance followed by Bonferroni's post hoc test. Multivariate Cox regression analysis was used to analyze overall survival in association with clinicopathological features and VASP/HIF-1 $\alpha$ expression in lung adenocarcinoma. $\mathrm{P}<0.05$ was considered to indicate a statistically significant difference.

\section{Results}

Expression of VASP in regulation of proliferation and adhesion of A549 cells. To identify the effects of TNF- $\alpha$ on the proliferative and adhesive ability of lung carcinoma, dose-response and time-course experiments were performed using A549 and H226 cells. Cell viability was analyzed using an MTT assay and the extracellular matrix component laminin was used to analyze adhesive ability. The results suggested that TNF- $\alpha$ did not cause cell death at low concentrations, which is consistent with our previous study (33). TNF- $\alpha$ inhibited proliferation and adhesion of A549 and H226 cells in a dose-dependent manner (Fig. 1A and B). Inhibition of cell proliferation was evident when cells were treated with $120 \mathrm{ng} / \mathrm{ml} \mathrm{TNF-} \alpha$ for $24 \mathrm{~h}$, and cell viability rates decreased significantly (Fig. 1C). Therefore, TNF- $\alpha$ was used at a concentration of $120 \mathrm{ng} / \mathrm{ml}$ for $24 \mathrm{~h}$ in subsequent experiments.

VASP serves a critical function in regulating cell physiology and has been identified to be associated with various human diseases $(26,30)$. However, it remains unclear whether VASP is involved in the mechanism by which TNF- $\alpha$ inhibits lung carcinoma cell proliferation and adhesion. To investigate whether the inhibitory effects on cell proliferation and adhesion result from the regulation of VASP expression by TNF- $\alpha$, the protein and mRNA expression levels of VASP were analyzed in A549 and H226 cells. Treatment with a high concentration of TNF- $\alpha$ (120 or $240 \mathrm{ng} / \mathrm{ml}$ ) for $24 \mathrm{~h}$ effectively decreased VASP expression at the protein and mRNA levels in A549 cells (Fig. 1D and E). However, there was no significant difference in VASP expression at the protein or mRNA levels with TNF- $\alpha$ treatment in H226 cells (Fig. 1D and E). These results indicated that TNF- $\alpha$ treatment resulted in a significant downregulation of VASP expression in A549 cells, but not in $\mathrm{H} 226$ cells. In brief, these results suggest that VASP may be a contributor to antitumor activities of TNF- $\alpha$ in A549 cells.

To investigate the biological consequences of VASP overexpression or knockdown, mRNA and protein expression analysis were used to confirm the expression or suppression of VASP by transient transfection with pEGFP-C1-VASP or VASP shRNA (Fig. 1F and G). A cell viability assay indicated that overexpression of VASP caused a significant increase in the cell viability rate, whereas knockdown of VASP caused a decrease (Fig. 1H). Consistent with the cell viability results, a cell adhesion assay demonstrated that overexpression of VASP led to a significant increase in cell adhesive ability, whereas knockdown of VASP led to a decrease (Fig. 1I). As VASP promoted A549 cell proliferation and adhesion in the absence of TNF- $\alpha$, it was subsequently investigated whether VASP was required for the effects of TNF- $\alpha$. A549 cell viability was assessed following transient transfection with pEGFP-C1-VASP or VASP shRNA in the presence of TNF- $\alpha(120 \mathrm{ng} / \mathrm{ml})$. As expected, cell viability rates significantly decreased with TNF- $\alpha$ treatment (Fig. 1H). Exogenous overexpression of VASP increased cell viability rates compared with the control (pEGFP-C1) when cells underwent TNF- $\alpha$ treatment. Loss of VASP expression significantly decreased the cell viability rate compared with the control (Fig. 1H). These results indicated that TNF- $\alpha$-induced inhibition of cell proliferation was significantly enhanced by knockdown of VASP expression and that exogenous VASP expression partially rescued cells from TNF- $\alpha$ treatment-induced cell death. We hypothesized that VASP may be required for TNF- $\alpha$-induced inhibition of A549-cell proliferation. Additional experiments revealed that $\mathrm{TNF}-\alpha$-induced inhibition of cell adhesion was similarly promoted by pretreatment with the knockdown plasmid, and attenuated by exogenous VASP expression, which is consistent with the cell viability results (Fig. 1I). Overexpression of VASP increased cell adhesion rates in the presence of TNF- $\alpha$, whereas loss of VASP decreased the cell adhesion rates (Fig. 1I). These results suggest that VASP may be required for TNF- $\alpha$-induced inhibition of A549 cell adhesion. Together, these results suggest that VASP contributes to TNF- $\alpha$-induced inhibition of proliferation and adhesion of A549 cells in vitro.

$H I F-1 \alpha$ is required for TNF- $\alpha$-induced inhibition of proliferation and adhesion of A549 cells. Our previous study indicated that TNF- $\alpha$ significantly increases the activity of HIF-1 $\alpha$ in MCF-7 cells (33). HIF-1 $\alpha$ is a critical transcription factor that regulates a variety of biological processes, including cell survival, proliferation, apoptosis and differentiation through downstream signal transduction cascades (19). To investigate the function of HIF- $1 \alpha$ in TNF- $\alpha$-induced inhibition of cell proliferation and adhesion in lung cancer, protein expression and mRNA levels of HIF-1 $\alpha$ in TNF- $\alpha$-treated A549 cells were determined. Western blot results indicated that TNF- $\alpha$ effectively activated HIF-1 $\alpha$ protein expression in A549 cells treated with $120 \mathrm{ng} / \mathrm{ml} \mathrm{TNF}-\alpha$ for $24 \mathrm{~h}$ (Fig. 2A). The results of RT-qPCR indicated that HIFlA mRNA levels were also significantly increased in A549 cells treated similarly (Fig. 2B). Thus, these results suggest that HIF-1 $\alpha$ is upregulated by TNF- $\alpha$ in A549 cells.

To investigate the effect of HIF-1 $\alpha$ on the cell proliferative and adhesive ability, the protein and mRNA expression levels of HIF-1 $\alpha$ were analyzed by overexpression (pEGFP-C1-HIF-1 $\alpha$ ) and RNA interference (HIF-1 $\alpha$-siRNA) experiments in A549 cells (Fig. 2C and D). Cell viability assays identified that ectopic expression of HIF-1 $\alpha$ decreased cell viability 
A

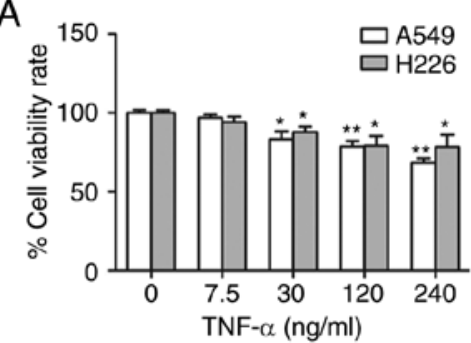

D

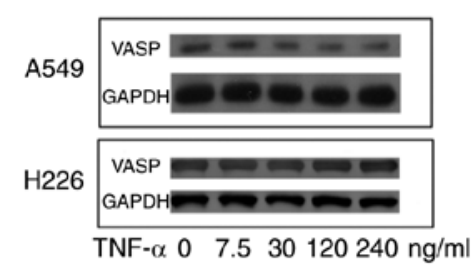

$\mathrm{F}$

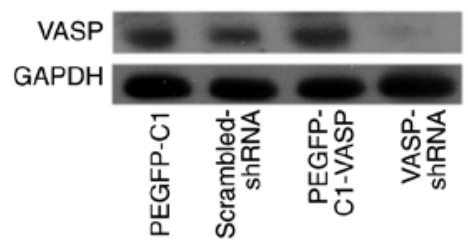

B
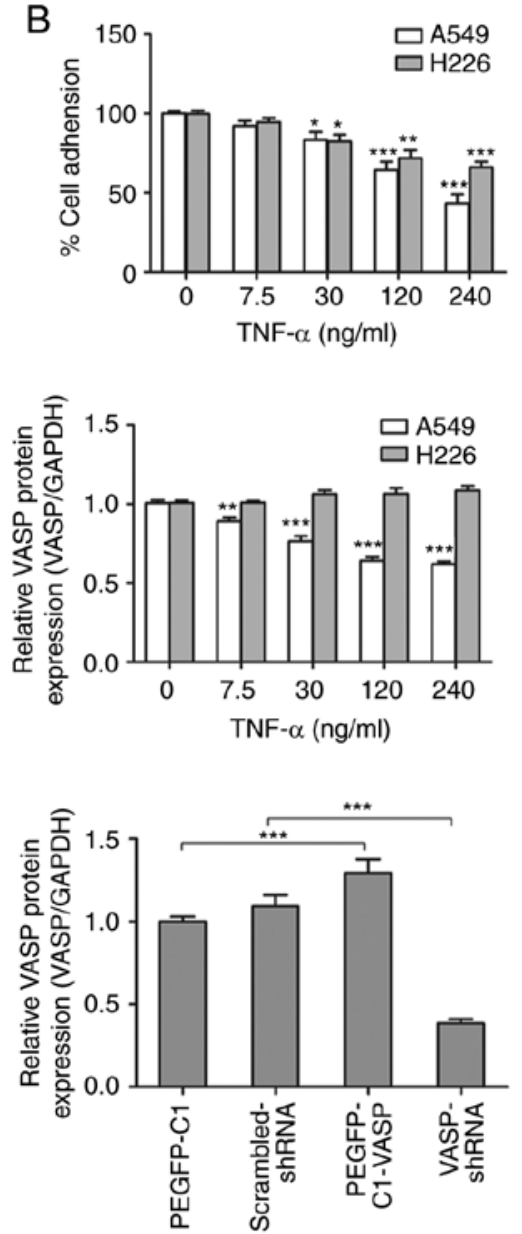

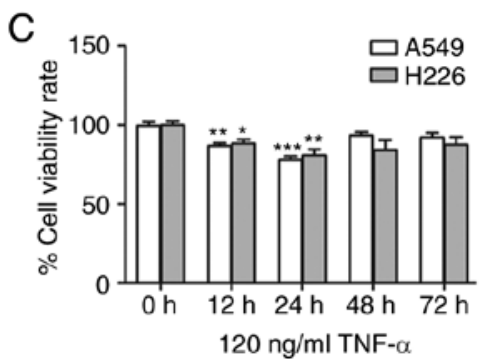

E

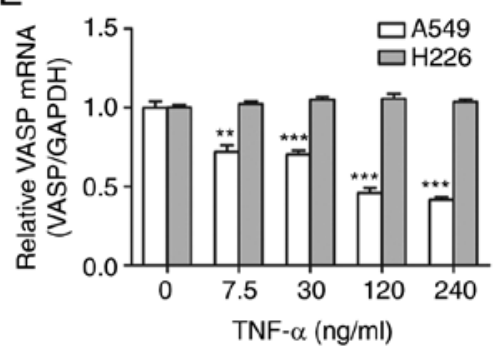

G

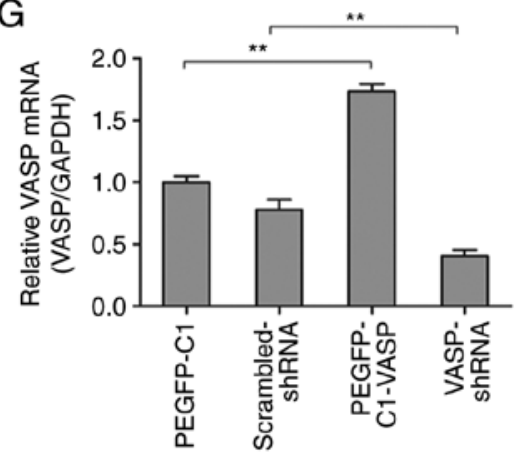

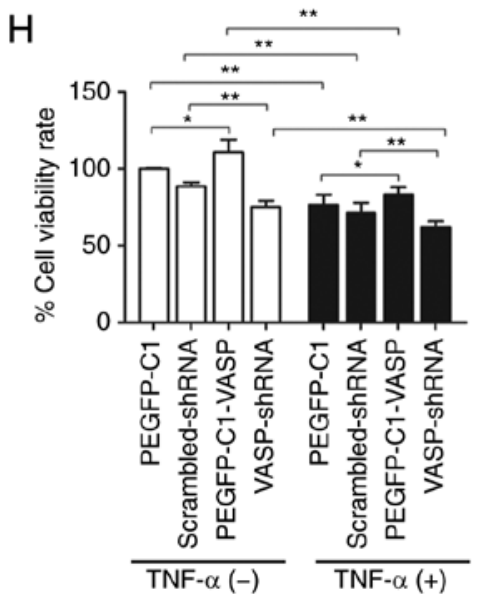

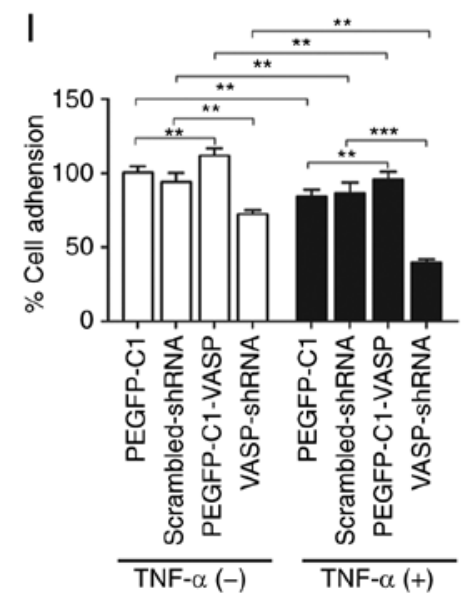

Figure 1. Expression of VASP and the regulation of proliferation and adhesion of A549 cells. (A) TNF- $\alpha$ dose-dependently decreases the viability of A549 and $\mathrm{H} 226$ lung cancer cells. ${ }^{*} \mathrm{P}<0.05,{ }^{* *} \mathrm{P}<0.01$ vs. untreated control. (B) TNF- $\alpha$ dose-dependently decreases the adhesion of A549 and $\mathrm{H} 226$ lung cancer cells. ${ }^{*} \mathrm{P}<0.05,{ }^{* *} \mathrm{P}<0.01,{ }^{* * *} \mathrm{P}<0.001$ vs. untreated control. (C) Time-course analysis of the viability of A549 and $\mathrm{H} 226$ cancer cells treated with $120 \mathrm{ng} / \mathrm{ml} \mathrm{TNF}-\alpha$. ${ }^{*} \mathrm{P}<0.05,{ }^{* *} \mathrm{P}<0.01,{ }^{* * *} \mathrm{P}<0.001$ vs. untreated control. TNF- $\alpha$ inhibited the protein and mRNA expression levels of VASP in A549, but not H226, cells. A549 and H226 cells were treated with TNF- $\alpha$ for $24 \mathrm{~h}$ prior to (D) western blot and (E) RT-qPCR analyses. GAPDH was used as an internal control. ${ }^{* *} \mathrm{P}<0.01,{ }^{* * *} \mathrm{P}<0.001$ vs. untreated control. (F) Western blotting and (G) RT-qPCR validation of VASP overexpression or knockdown by transient transfection with pEGFP-C1-VASP or VASP shRNA for $24 \mathrm{~h} .{ }^{* *} \mathrm{P}<0.01,{ }^{* * *} \mathrm{P}<0.001$. (H) Cell viability and (I) cell adhesion analysis following VASP overexpression or knockdown, with or without $120 \mathrm{ng} / \mathrm{ml}$ TNF- $\alpha$ treatment. The pEGFP-C1 vector or scrambled shRNA was used as negative control. ${ }^{*} \mathrm{P}<0.05,{ }^{* *} \mathrm{P}<0.01,{ }^{* * *} \mathrm{P}<0.001$. Results are presented as the mean \pm standard deviation of 3 independent experiments ( $n=6$ replicates). VASP, vasodilator-stimulated phosphoprotein; TNF- $\alpha$, tumor necrosis factor $\alpha$; RT-qPCR, reverse transcription-quantitative polymerase chain reaction; shRNA, short hairpin RNA.

in the absence of TNF- $\alpha$, whereas siRNA-mediated knockdown of HIF-1 $\alpha$ increased viability of A549 cells (Fig. 2E). However, TNF- $\alpha$ treatment significantly decreased cell viability rates (Fig. 2E). Exogenous overexpression of HIF-1 $\alpha$ decreased cell viability rates when A549 cells were treated with TNF- $\alpha$ compared with the control (pEGFP-C1), similar to the results obtained in the absence of TNF- $\alpha$ (Fig. 2E). HIF-1 $\alpha$ deficiency significantly blocked cell death induced 
A

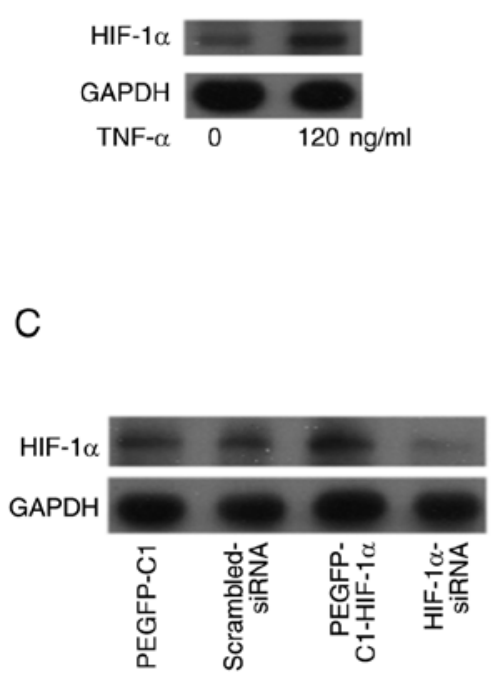

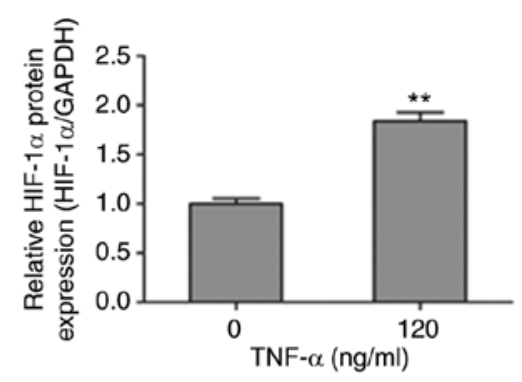

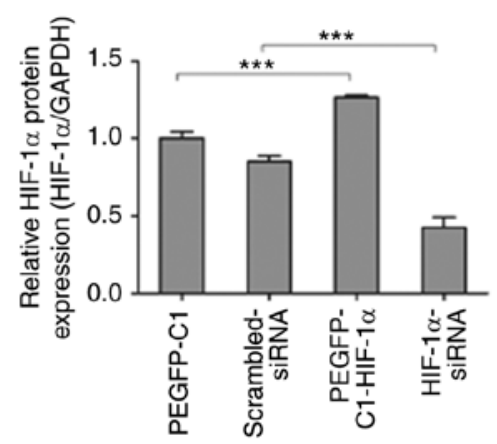

B

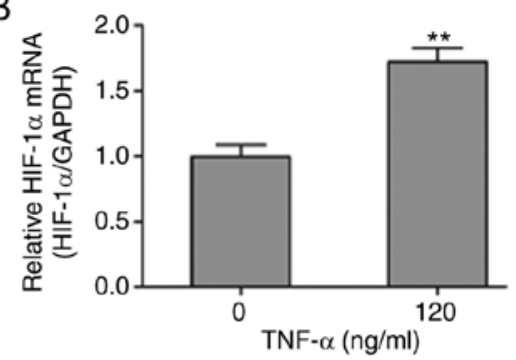

D

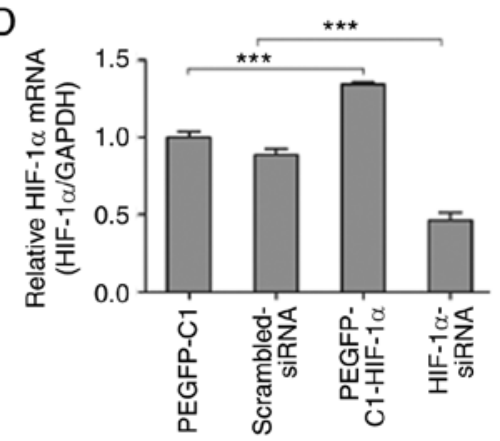

$E$

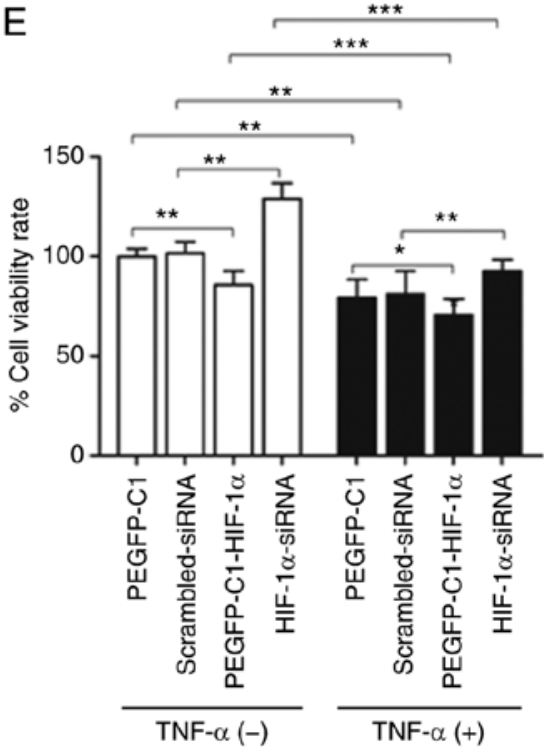

$\mathrm{F}$

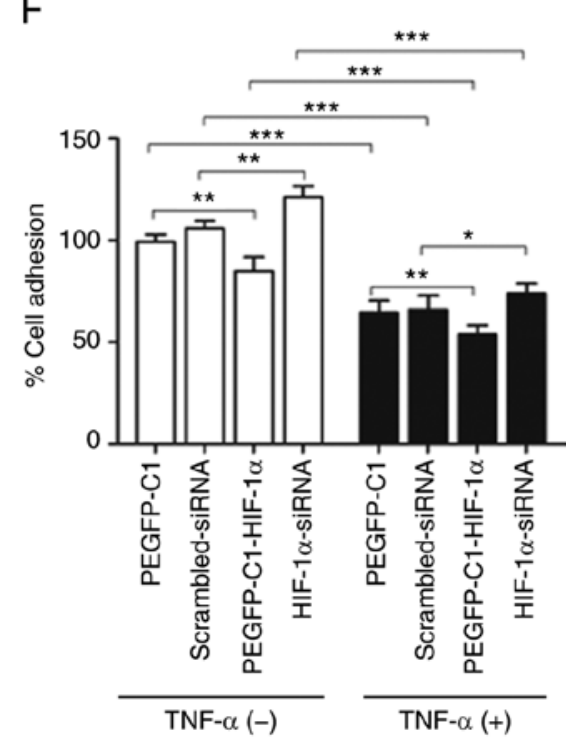

Figure 2. HIF-1 $\alpha$ is required for TNF- $\alpha$-induced inhibition of proliferation and adhesion of A549 cells. TNF- $\alpha$ at $120 \mathrm{ng} / \mathrm{ml}$ for $24 \mathrm{~h}$ upregulated the protein and mRNA expression levels of HIF-1 $\alpha$ in A549 cells, as determined by (A) western blot and (B) RT-qPCR analyses. ${ }^{* *} \mathrm{P}<0.01$ vs. untreated cells. (C) Western blotting and (D) RT-qPCR validation of HIF-1 $\alpha$ overexpression or knockdown by transient transfection with pEGFP-C1-HIF-1 $\alpha$ or HIF-1 $\alpha$-siRNA for $24 \mathrm{~h}$. ${ }^{* * * *} \mathrm{P}<0.001$. (E) Cell viability and (F) cell adhesion analysis of cells exhibiting HIF-1 $\alpha$ overexpression or knockdown. The pEGFP-C1 vector or scrambled siRNA was used as a negative control. GAPDH was used as an internal control. ${ }^{*} \mathrm{P}<0.05,{ }^{* *} \mathrm{P}<0.01,{ }^{* * *} \mathrm{P}<0.001$. Results are presented as the mean \pm standard deviation of 3 independent experiments ( $n=6$ replicates). HIF- $1 \alpha$, hypoxia-inducible factor $1 \alpha$; TNF- $\alpha$, tumor necrosis factor $\alpha$; RT-qPCR, reverse transcription-polymerase chain reaction; siRNA, short interfering RNA.

by TNF- $\alpha$ treatment in A549 cells (Fig. 2E). These results suggest that the viability response induced by TNF- $\alpha$ was at least partially HIF-1 $\alpha$-dependent. The cell adhesion assay demonstrated that TNF- $\alpha$-induced inhibition of cell adhesion was also attenuated by knockdown of HIF-1 $\alpha$, and enhanced by HIF-1 $\alpha$ overexpression (Fig. 2F), which was consistent with the cell viability results. The results of these complementary experiments suggest that HIF-1 $\alpha$ may be a negative regulator of proliferative and adhesive ability in A549 cells. Therefore, we hypothesize that TNF- $\alpha$ upregulates HIF- $1 \alpha$, and that HIF-1 $\alpha$ affects downstream proteins and regulates the proliferative and adhesive ability of A549 cells.
HIF-1 $\alpha$ inhibits VASP expression at the transcriptional level. To determine whether the suppression of VASP by TNF- $\alpha$ in A549 lung adenocarcinoma cells was dependent on HIF-1 $\alpha$, the VASP genomic sequence was analyzed, and 2 canonical HBSs located in the VASP promoter region were identified. Next, the HBS sequences were cloned into a luciferase reporter, and a luciferase assay was performed to assess the regulatory function of HIF-1 $\alpha$ (Fig. 3A). HIF-1 $\alpha$ significantly suppressed the VASP promoter activity, and lack of the HBSs abrogated this suppression in A549 cells (Fig. 3B). The results indicated that HIF-1 $\alpha$ bound to the HBS compared with other regions. 
A
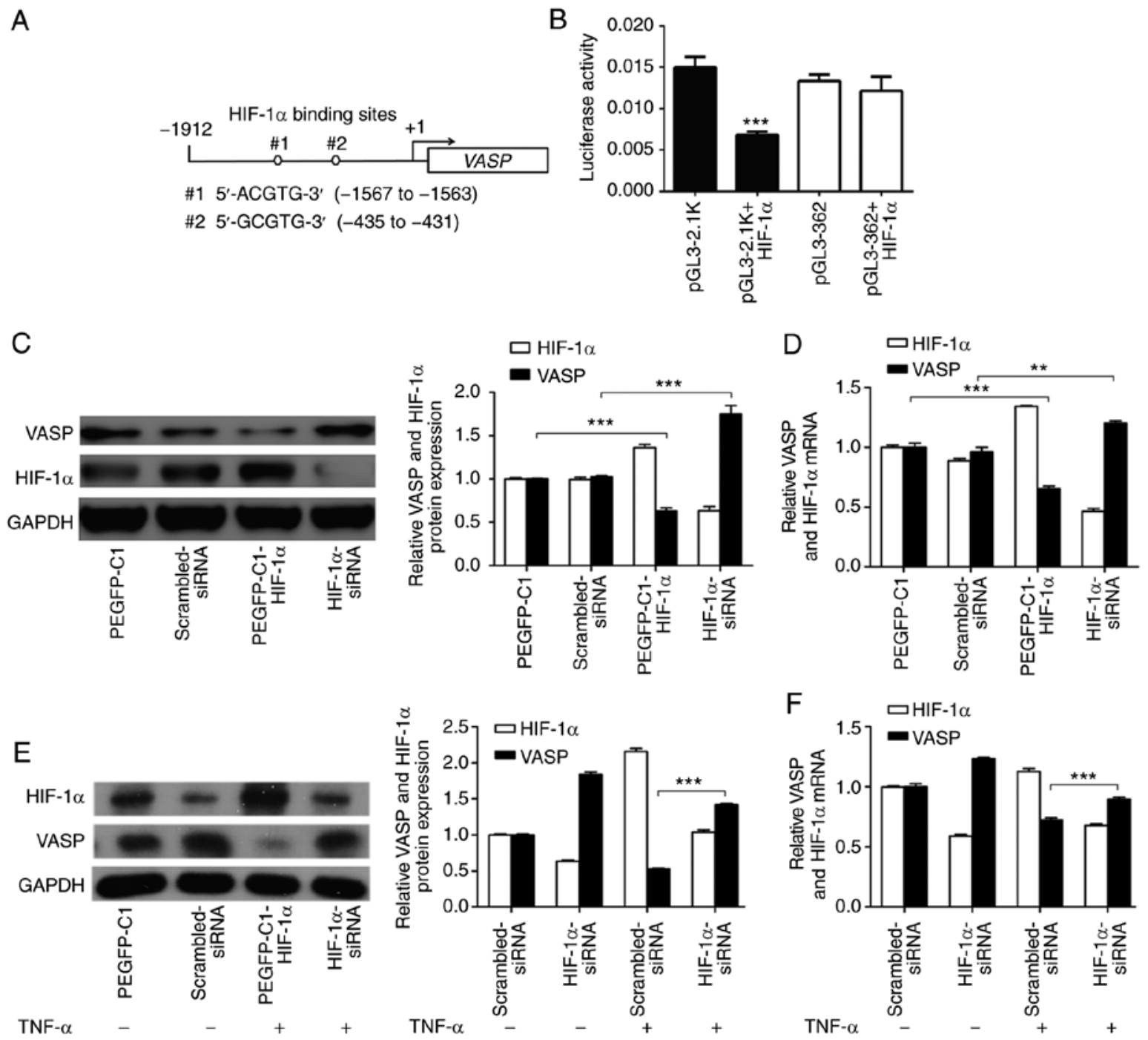

Figure 3. HIF-1 $\alpha$ inhibits VASP expression at the transcriptional level. (A) HIF-1 $\alpha$ regulates VASP transcription. The VASP promoter region of the HBS. (B) The HBS region and the VASP promoter sequence with the HBS region deleted were cloned into pGL3 luciferase reporter plasmids. Reporter plasmid, pRL Renilla luciferase vector and pEGFP-C1-HIF- $\alpha$ plasmid were transfected into A549 cells. ${ }^{* * *} \mathrm{P}<0.001$ vs. pGL3-2.1K. (C) Western blot and (D) RT-qPCR analyses in HIF-1 $\alpha$ overexpression or knockdown. pEGFP-C1 vector or scrambled siRNA was used as negative control. TNF- $\alpha$ regulates VASP, mediated by HIF-1 $\alpha$. ${ }^{* *} \mathrm{P}<0.01,{ }^{* * *} \mathrm{P}<0.001$. A549 cells transfected with HIF-1 $\alpha$-siRNA, in the presence or absence of TNF- $\alpha(120 \mathrm{ng} / \mathrm{ml})$ for $24 \mathrm{~h}$, were subjected to (E) western blot and (F) RT-qPCR analyses. GAPDH was used as an internal control. Scrambled siRNA was used as negative control. ${ }^{* * * *} \mathrm{P}<0.001$. Results are presented as the mean \pm standard deviation of 3 independent experiments. HIF-1 $\alpha$, hypoxia-inducible factor $1 \alpha$; VASP, vasodilator-stimulated phosphoprotein; HBS, HIF-1 $\alpha$-binding site; RT-qPCR, reverse transcription-quantitative polymerase chain reaction; TNF- $\alpha$, tumor necrosis factor $\alpha$; siRNA, short interfering RNA.

To further verify that HIF-1 $\alpha$ signaling directly regulates VASP expression, overexpression and knockdown experiments were performed in A549 cells. Consistent with Fig. 2C, western blot analysis suggested that VASP expression was significantly increased by siRNA-mediated knockdown of HIF-1 $\alpha$ (Fig. 3C). By contrast, ectopically upregulated expression of HIF-1 $\alpha$ caused a decrease in VASP expression in A549 cells (Fig. 3C). In addition, RT-qPCR results suggested further that the VASP mRNA expression level was significantly decreased by overexpression of HIF- $1 \alpha$ and increased by knockdown of HIF-1 $\alpha$ (Fig. 3D). These results indicated that $V A S P$ is a direct target of HIF-1 $\alpha$, and suggested a negative association between the expression of the 2 proteins in A549 cells.

TNF- $\alpha$ treatment resulted in downregulation of VASP expression in A549 cells and caused upregulation of HIF-1 $\alpha$ expression, suggesting that TNF- $\alpha$ may regulate VASP in a HIF-1 $\alpha$-dependent manner (Figs. 1D and E, 2A and B). To determine the association between VASP and HIF-1 $\alpha$ following TNF- $\alpha$ treatment, western blot and RT-qPCR analyses were performed in A549 cells (Fig. 3E and F). The results indicated that knockdown of HIF-1 $\alpha$ increased VASP expression in the absence of TNF- $\alpha$, and that VASP expression was partially suppressed at the protein and mRNA levels when cells were treated with TNF- $\alpha$ (Fig. 3C-F). Additionally, HIF-1 $\alpha$-knockdown significantly restored VASP protein expression and mRNA levels when A549 cells were treated with TNF- $\alpha$ compared with control (scrambled siRNA) (Fig. 3E and F). These results suggest that HIF- $1 \alpha$ acts upstream of the VASP signaling pathway following TNF- $\alpha$ treatment in A549 cells.

To further investigate the biological consequences of the HIF-1 $\alpha /$ VASP signaling pathway in response to TNF- $\alpha, \mathrm{H} 226$ cells were used. mRNA and protein analysis 
A
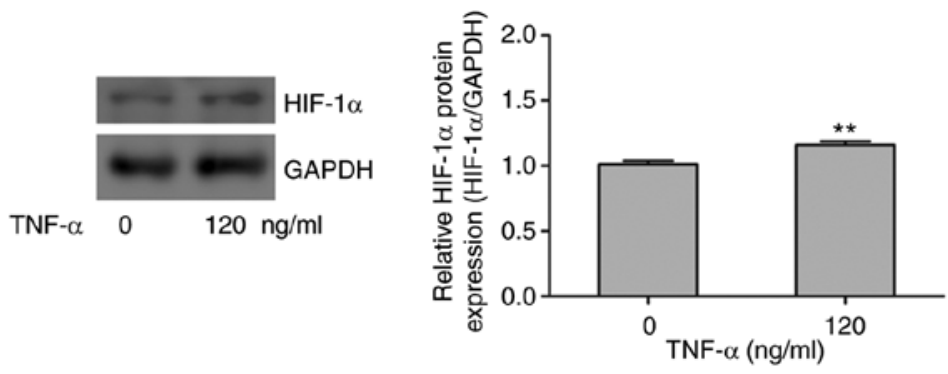

B
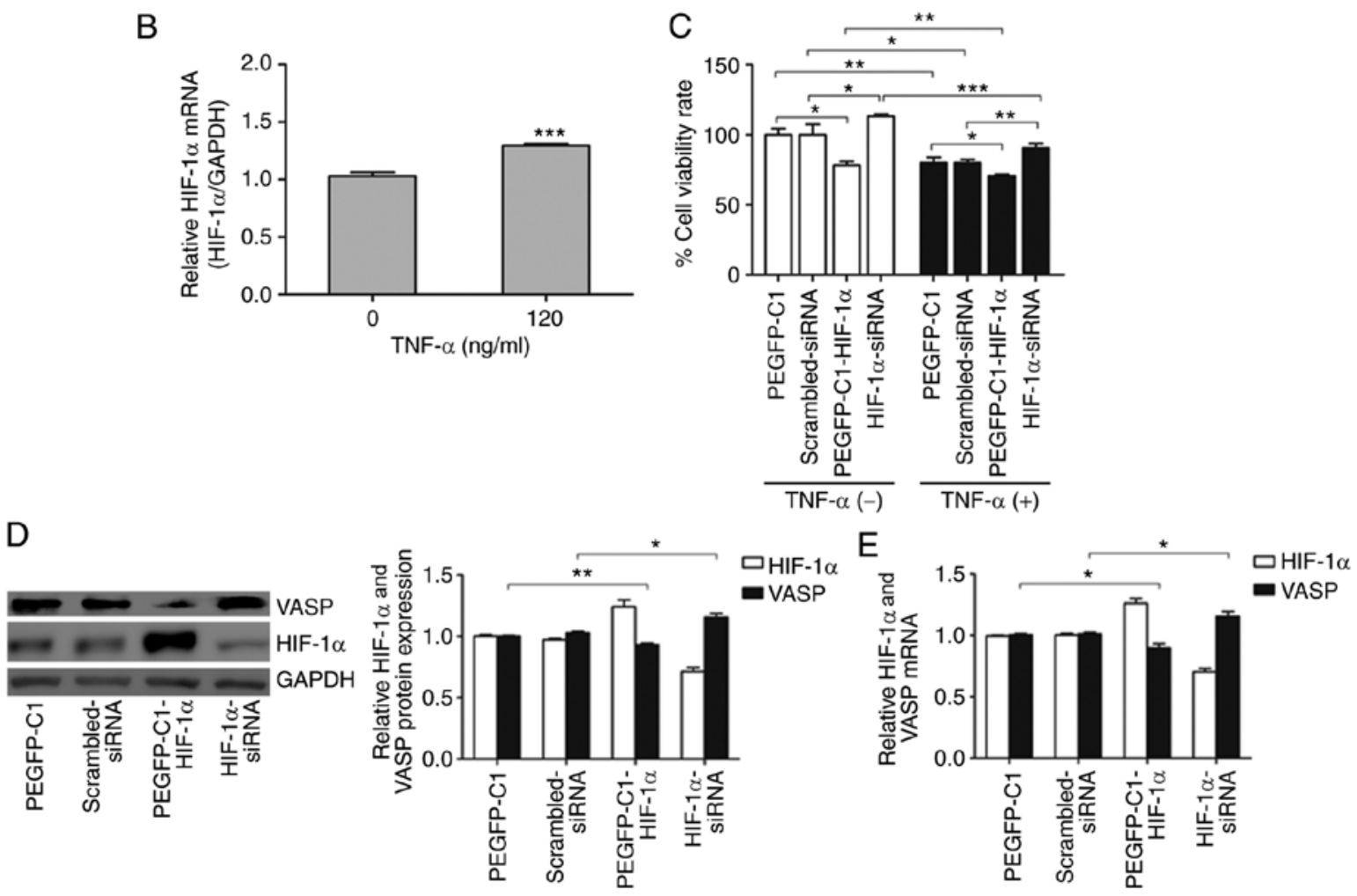

Figure 4. HIF-1 $\alpha$ is involved in TNF- $\alpha$-induced inhibition of $\mathrm{H} 226$ cell proliferation. H226 cells treated with $120 \mathrm{ng} / \mathrm{ml} \mathrm{TNF}-\alpha$ for $24 \mathrm{~h}$ were subjected to (A) western blot and (B) RT-qPCR analyses. (C) Cell viability, (D) western blot and (E) RT-qPCR analyses of HIF-1 $\alpha$-overexpressing or -knockdown cells. GAPDH was used as a loading control. The pEGFP-C1 vector or scrambled siRNA was used as a negative control. ${ }^{*} \mathrm{P}<0.05,{ }^{* *} \mathrm{P}<0.01,{ }^{* * *} \mathrm{P}<0.001$. Results are presented as the mean \pm standard deviation of 3 independent experiments ( $n=6$ replicates). HIF-1 $\alpha$, hypoxia-inducible factor $1 \alpha$; TNF- $\alpha$, tumor necrosis factor $\alpha$; RT-qPCR, reverse transcription-polymerase chain reaction; VASP, vasodilator-stimulated phosphoprotein; siRNA, short interfering RNA.

revealed that TNF- $\alpha$ promoted HIF-1 $\alpha$ expression in $\mathrm{H} 226$ cells (Fig. 4A and B). Additionally, the function of HIF-1 $\alpha$ on $\mathrm{H} 226$ cell proliferation was investigated. Exogenous overexpression of HIF-1 $\alpha$ significantly decreased cell viability, and HIF- $1 \alpha$ deficiency partially rescued $\mathrm{H} 226$ cells from TNF- $\alpha$-induced cell death (Fig. 4C). However, HIF-1 $\alpha$ inhibited VASP expression in H226 cells (Fig. 4D and E). In this context, HIF- $1 \alpha$ acted as a transcriptional activator, downregulating the expression of a large number of genes, including $V A S P$, although the direct targets were not identified. VASP may be regulated by a subset of transcriptional activators in gene expression regulatory networks; however, this remains to be elucidated.

TNF- $\alpha$ inhibits transplanted tumor growth in vivo in the xenograft model. To investigate the antitumor effects of TNF- $\alpha$ in vivo, nude mice bearing established A549 tumor xenografts were treated with vehicle (saline) or TNF- $\alpha$ (54 $\mu \mathrm{g} / \mathrm{kg}$ body weight) by intraperitoneal injection. The body weight of each mouse was measured every 3 days. Decreased body weights were observed in TNF- $\alpha$-treated mice (Fig. 5A), although these were typically not significantly different from body weights of control mice.

Mice were treated as aforementioned, and the volume of the xenograft tumor was determined every 3 days. The relative tumor volume (RTV) of tumor-bearing mice treated with vehicle increased linearly, and TNF- $\alpha$ significantly inhibited tumor growth compared with vehicle ( $\mathrm{P}<0.05$; Fig. 5B).

Consistent with the tumor volume analysis, the average tumor weights associated with vehicle and TNF- $\alpha$ treatment were 0.16 and $0.11 \mathrm{~g}$, respectively $(\mathrm{P}<0.05$; Fig. $5 \mathrm{C})$. Therefore, these results suggested that TNF- $\alpha$ was effective against tumors and caused minimal damage to normal cells (Fig. 5A-C).

The tumor tissues of nude mice treated with the vehicle were nodular, encapsulated, exhibited medium hardness and no distant infiltration, with a gray cut surface and festered (data not shown). In addition, tumor cells were arranged densely, exhibiting significant atypia, large nuclei, abundant 
A

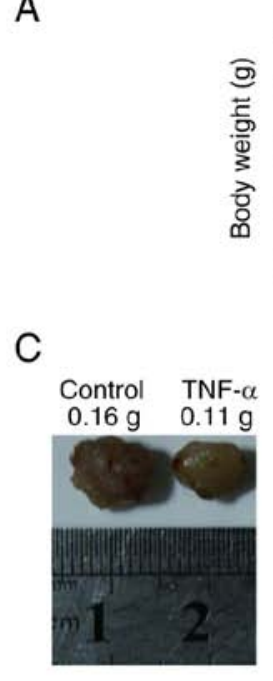

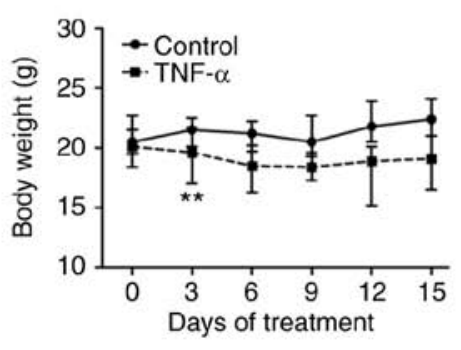

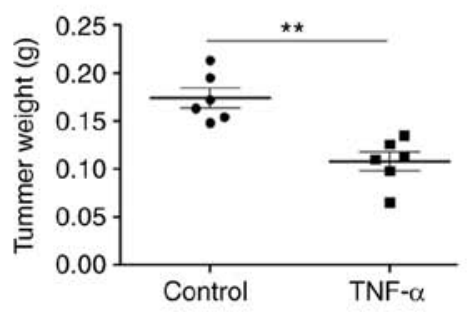

D
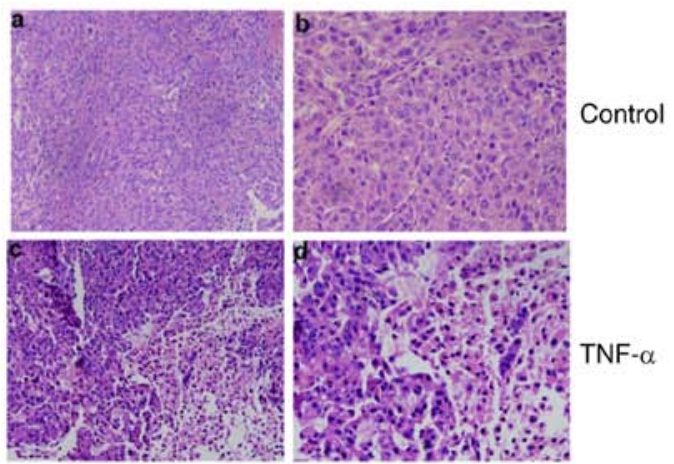

E
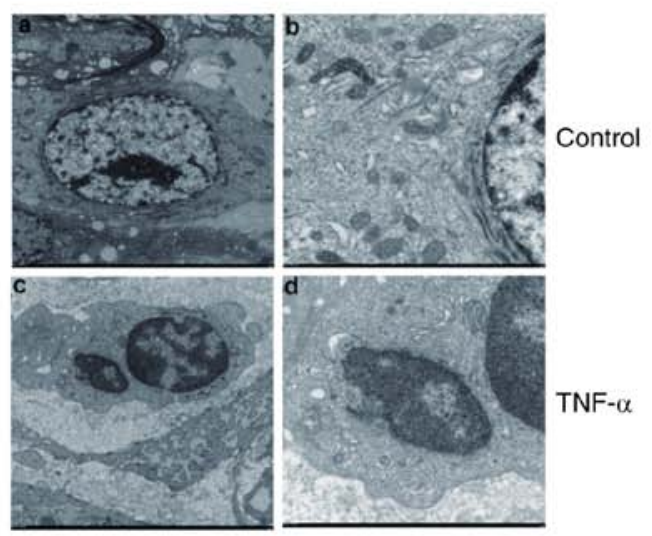

B
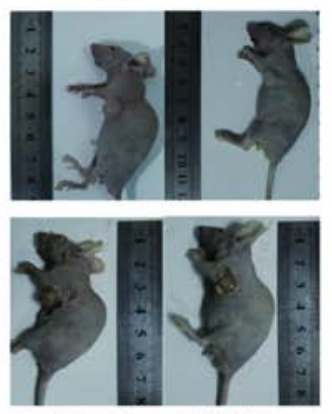

Control

TNF- $\alpha$

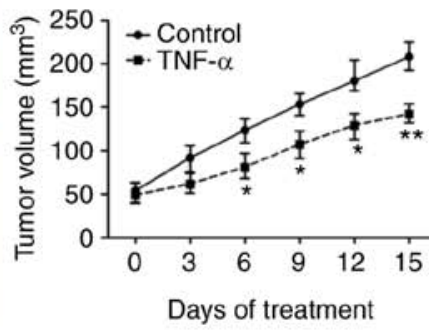

F

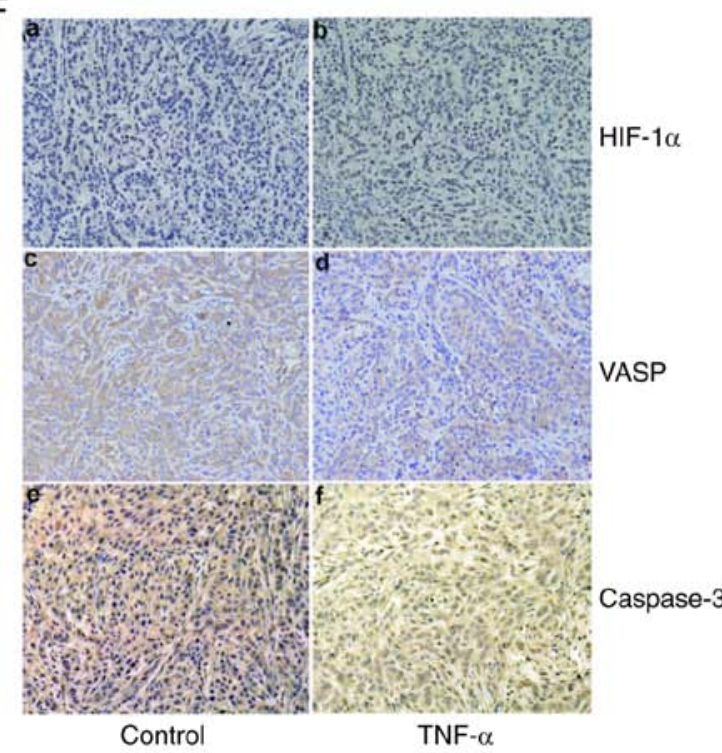

G

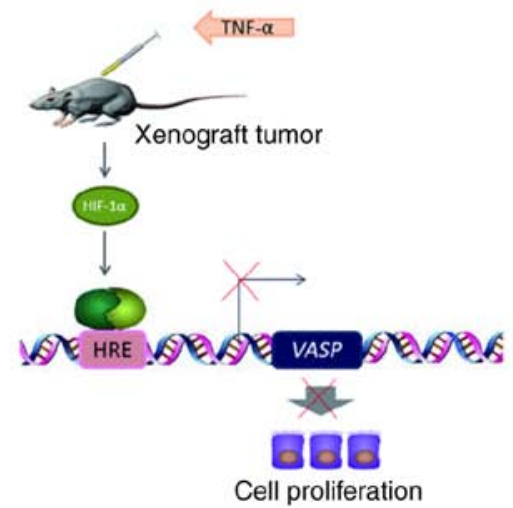

Figure 5. TNF- $\alpha$ inhibits transplanted tumor growth in vivo. (A) Effect of TNF- $\alpha$ on the body weight of xenograft tumors in nude mice. The body weights of mice were determined every 3 days. (B) TNF- $\alpha$ decreased the volume of xenograft tumors in nude mice. Average tumor volumes were determined every 3 days. (C) TNF- $\alpha$ decreased the weight of xenograft tumors in nude mice. Average tumor weights at the end of the indicated treatment are presented. (D) TNF- $\alpha$ affects the tissues of xenograft lung tumors. Histopathological changes of the xenograft in (a and b) control mice, or (c and d) following TNF- $\alpha$ treatment, observed by hematoxylin and eosin staining (a and c, x200 magnification; b and d, x400 magnification). (E) TNF- $\alpha$ affects the ultrastructure of xenograft lung tumor tissues. Morphological changes of xenograft tumor tissues in (a and b) control mice, or ( $c$ and d) mice treated with TNF- $\alpha$, visualized by transmission electron microscopy. (a) Tumor tissues in the control group: Large tumor cells, normal morphology, approximately circular or oval in shape, large and irregular nuclei, rich in euchromatin, homogeneous in shape; (c) cytoplasm abundant, mitochondria and other organelles were visible. (b) TNF- $\alpha$ treatment group tumor tissues: Nucleus heterochromatin increased with cohesion, common tumor cell apoptosis; (d) formation of apoptotic bodies. (a, x2,000 magnification; b, x2,500, magnification; c and d, x7,000 magnification). (F) TNF- $\alpha$ affected HIF-1 $\alpha$, VASP and caspase-3 expression in xenograft lung tumor tissues. Immunohistochemistry for (a and b) HIF-1 $\alpha$, (c and d) VASP and (e and f) caspase-3 in xenograft tumor tissues of (a, c and e) control mice or (b, d and f) treated mice. (a-f, x200 magnification). (G) Schematic model of the decrease in VASP gene expression following TNF- $\alpha$ treatment. The extracellular signal molecule causes HIF-1 $\alpha$ activation, binding to the promoter region and resulting in the downregulation of VASP. TNF- $\alpha$, tumor necrosis factor $\alpha$; HIF-1 $\alpha$, hypoxia-inducible factor $1 \alpha$; VASP, vasodilator-stimulated phosphoprotein; HRE, hypoxia-response element. ${ }^{*} \mathrm{P}<0.05,{ }^{* *} \mathrm{P}<0.01$.

cytoplasm, and minimal intercellular substance were observed by H\&E staining (Fig. 5D-a and -b).
When mice were treated with TNF- $\alpha$, the tissues of xenograft lung tumors exhibited significant pathological 
Table I. Immunohistochemistry analysis of HIF-1 $\alpha$, VASP and caspase-3 expression of xenograft lung tumor tissues.

\begin{tabular}{|c|c|c|c|c|c|c|c|c|c|c|}
\hline & \multirow[b]{2}{*}{ Cases (n) } & \multicolumn{3}{|c|}{ HIF-1 $1 \alpha$} & \multicolumn{3}{|c|}{ VASP } & \multicolumn{3}{|c|}{ Caspase-3 } \\
\hline & & + & ++ & +++ & + & ++ & +++ & + & ++ & +++ \\
\hline Control & 6 & 2 & 3 & 1 & 1 & 1 & 4 & 2 & 2 & 2 \\
\hline TNF- $\alpha$ & 6 & 0 & 3 & 3 & 2 & 3 & 1 & 1 & 2 & 3 \\
\hline
\end{tabular}

,+++ and +++: Indicate weak, moderate or strong staining intensity, respectively. HIF-1 $\alpha$, hypoxia-inducible factor $1 \alpha$; VASP, vasodilator-stimulated phosphoprotein; TNF- $\alpha$, tumor necrosis factor $\alpha$.

A

\section{A}

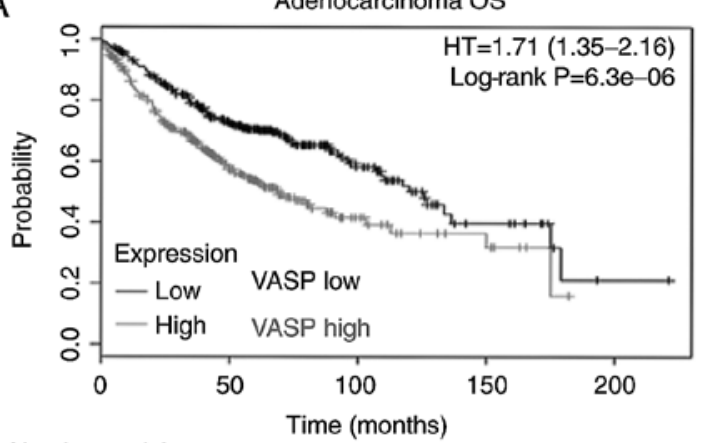

Number at risk

Low $361 \quad 210 \quad 49$

High 359

C

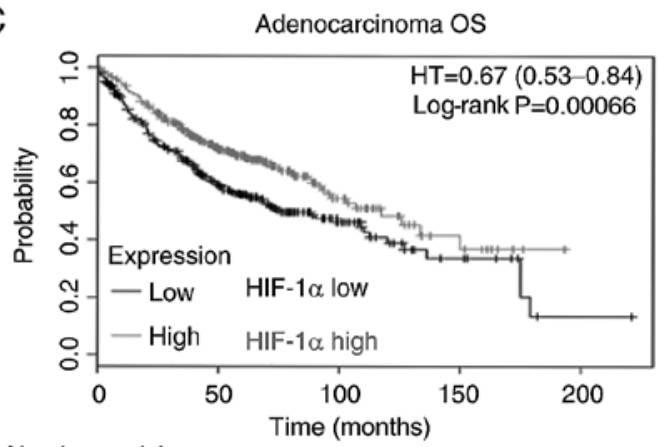

Number at risk

$\begin{array}{llllcl}\text { Low } & 360 & 163 & 34 & 10 & 1 \\ \text { High } & 360 & 185 & 35 & 9 & 0\end{array}$
B

B Squamous cell carcinoma OS

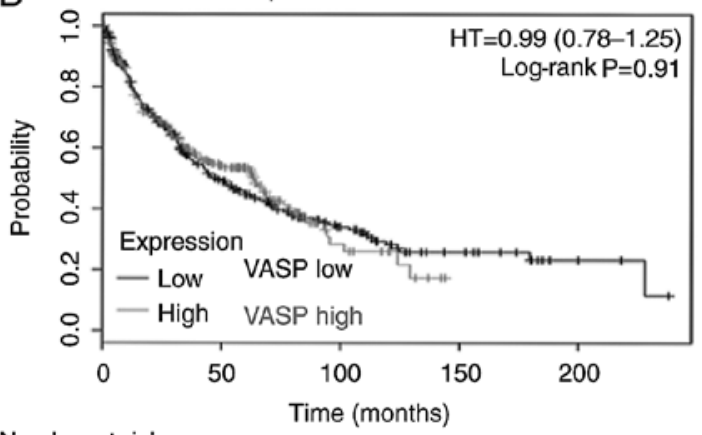

Number at risk

$\begin{array}{cccccc}\text { Low } & 263 & 95 & 42 & 15 & 4 \\ \text { High } & 261 & 84 & 12 & 0 & 0\end{array}$

D Squamous cell carcinoma OS

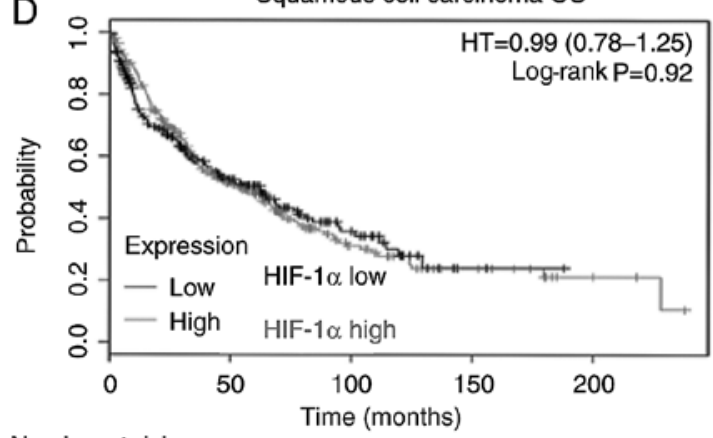

Number at risk

$\begin{array}{lllll}\text { Low } 262 & 82 & 24 & 2 & 0\end{array}$

Figure 6. High VASP or low HIF-1 $\alpha$ expression is associated with poor prognosis in lung adenocarcinoma. Kaplan-Meier plots indicating overall survival of patients bearing VASP ${ }^{\text {hi }}$ tumors of the (A) lung adenocarcinoma and (B) squamous cell carcinoma subtypes, and overall survival of patients bearing $H I F 1 A^{\text {hi }}$ tumors of the (C) lung adenocarcinoma and (D) squamous cell carcinoma subtypes. Hazard ratios, confidence intervals and log-rank P-values are presented. VASP, vasodilator-stimulated phosphoprotein; HIF-1 $\alpha$, hypoxia-inducible factor 1 $\alpha$; OS, overall survival; HR, hazard ratio.

changes, including irregular necrosis, hemorrhage regions and flaky eosinophilic structures (Fig. 5D-c and -d).

Transmission electron microscopy was used to observe the ultra-pathological changes of xenograft lung tumors. Tumor cells in the control group were large, and approximately circular or oval, with large and irregular nuclei (Fig. 5E-a and -b). In contrast, tumor cells in the TNF- $\alpha$-treated group were distributed sparsely, and cell size was generally lower compared with that of control, with evident cell debris. Parts of the cell envelope and nuclear membrane were significantly swollen, and cytoplasmic mitochondria were swollen with a rounded shape, ridge-reduced and demonstrating malalignment (Fig. 5E-c and -d).
Positive HIF-1 $\alpha$ protein expression in the nucleus, and VASP and caspase-3 protein expression in the cytoplasm exhibited brown granular or clustered distribution (Fig. 5F). Following TNF- $\alpha$ treatment for 15 days, HIF-1 $\alpha$ was overexpressed in a number of xenograft lung tumors compared with the control group (Fig. 5F-a and -b). Marked VASP staining intensity was easily observed in the control group, but not in the therapeutic groups (Fig. 5F-c and -d). Furthermore, marked expression of caspase- 3 was present in TNF- $\alpha$-treated xenograft lung tumor tissue (Fig. 5F-e and -f). Quantification analysis for HIF-1 $\alpha$, VASP and caspase-3 protein expression was performed (Table I). 
Table II. Multivariate Cox regression analysis of overall survival in association with clinicopathological features and VASP expression in lung adenocarcinoma.

\begin{tabular}{llc}
\hline Characteristic & P-value & Hazard ratio (95\% CI) \\
\hline Stage & 0.1367 & $3.64(0.66-19.99)$ \\
AJCC stage T & $0.0096^{\mathrm{a}}$ & $2.52(1.25-5.06)$ \\
AJCC stage N & 0.9009 & $0.9(0.16-4.98)$ \\
Sex & 0.1698 & $1.5(0.84-2.68)$ \\
Smoking history & 0.4203 & $0.72(0.32-1.6)$ \\
VASP & $0.0256^{\mathrm{a}}$ & $1.93(1.08-3.44)$ \\
\hline
\end{tabular}

${ }^{\mathrm{a}} \mathrm{P}<0.05$. VASP, vasodilator-stimulated phosphoprotein; CI, confidence interval; AJCC, American Joint Committee on Cancer; T, Tumor; N, Node.

Given these results in the A549 cell line and tumor xenograft model, we propose a schematic model for the decrease in VASP expression mediated by TNF- $\alpha$ treatment (Fig. 5G).

Long non-coding RNAs (IncRNAs) have been identified to be dysregulated in various diseases. IncRNA-LET has been identified to serve a key function in the metastasis of certain solid tumors by regulating HIF-1 $\alpha$ (32). RT-qPCR was used to detect the mRNA expression levels of IncRNA-LET in xenograft lung tumor tissues in nude mice. The mRNA expression levels of $I n c R N A-L E T$ were decreased in the therapeutic group compared with in the control (data not shown). These results suggest that the IncRNA-LET-associated molecular regulation pathway may be involved in the TNF- $\alpha$-mediated decrease in the HIF-1 $\alpha$ expression level; however, the specific regulatory mechanism requires further investigation.

High VASP or low HIF-1 $\alpha$ expression is associated with poor prognosis in lung adenocarcinoma. Since VASP expression in paraffin-embedded tissue specimens in lung cancer was significantly higher compared with that of the control, the association between VASP expression and outcome was investigated using the online KM-Plotter website for lung cancer using public data $(36,37)$. Patients with lung adenocarcinoma were categorized using the median value of VASP expression, and high expression of VASP mRNA was associated with a significant decrease in overall survival rates (Fig. 6A). No such association was observed among patients with lung squamous cell carcinoma subtypes (Fig. 6B). These data suggest that VASP expression may serve a critical function in lung adenocarcinoma. It was then analyzed whether the HIFIA mRNA expression was associated with outcome in lung cancer. Coincidently, lower HIF-1 $\alpha$ expression in lung adenocarcinoma was associated with poor prognosis, whereas no association was evident among patients with squamous cell carcinoma subtypes (Fig. 6C and D). In addition, multivariate analysis indicated that VASP expression was associated with overall survival, independent of sex, smoking history and tumor stage (Table II). However, HIF-1 $\alpha$ expression was not an independent predictor of overall survival (Table III). These results strongly support the hypothesis that VASP expression may be a valuable prognostic biomarker and have a significant
Table III. Multivariate Cox regression analysis of overall survival in association with clinicopathological features and HIF-1 $\alpha$ expression in lung adenocarcinoma.

\begin{tabular}{llc}
\hline Characteristic & P-value & Hazard ratio (95\% CI) \\
\hline Stage & 0.2392 & $2.78(0.51-15.31)$ \\
AJCC stage T & $0.0085^{\mathrm{a}}$ & $2.57(1.27-5.18)$ \\
AJCC stage N & 0.8344 & $1.2(0.21-6.79)$ \\
Sex & 0.1616 & $1.53(0.84-2.75)$ \\
Smoking history & 0.844 & $0.92(0.42-2.03)$ \\
HIF-1 $\alpha$ & 0.8016 & $1.08(0.61-1.89)$ \\
\hline
\end{tabular}

${ }^{\mathrm{a}} \mathrm{P}<0.05$. HIF- $1 \alpha$, hypoxia-inducible factor $1 \alpha ; \mathrm{CI}$, confidence interval; AJCC, American Joint Committee on Cancer; T, Tumor; N, Node.

effect on the clinical management of patients with lung adenocarcinoma.

\section{Discussion}

The treatment of lung adenocarcinoma has been advanced by the development of multiple therapies, including surgery, chemotherapy, radiotherapy and molecular targeted therapy (38). However, the high heterogeneity and disorder of tumor cells present challenges in cancer research. The results of the present study indicated a function of VASP protein in TNF- $\alpha$-induced lung cancer cell death. The ability of TNF- $\alpha$ to activate HIF-1 $\alpha$, which binds to the VASP promoter and suppresses its transcription, was also demonstrated, suggesting that VASP acts downstream of the TNF- $\alpha /$ HIF-1 $\alpha$ signaling pathway.

As a cytokine, TNF- $\alpha$ may lead to either promotion or prevention of tumor growth, depending on the dose or route of injection, and the type of tumor model (13-15). In 3LL-A9 Lewis lung carcinoma cells transplanted into C57BL/6 mice, TNF- $\alpha$ together with interferon $\alpha$ and perforin participated in T and natural killer cell-mediated elimination of carcinoma cells, demonstrating robust antitumor activity $(39,40)$. Targeted tumor endothelium delivering a hybrid adeno-associated virus phage vector expressing TNF- $\alpha$ resulted in apoptosis in tumor vessels, and significant inhibition of human melanoma xenograft tumor growth (41). In agreement, it was demonstrated in the present study that TNF- $\alpha$ directly inhibited A549 cell proliferation and adhesion, and xenograft tumor growth in nude mice. However, the underlying molecular mechanism for TNF- $\alpha$ inhibition of tumor growth remains unknown and requires further investigation.

VASP is an actin-associated protein, associated with tumor progression and metastasis via regulation of cell adhesion, migration and invasion. Previous studies demonstrated that a decrease in VASP expression significantly inhibited the proliferation and migration of MCF-7 luminal breast cancer cells and BGC-823 gastric cancer cells $(28,32,42)$. Dertsiz et al (36) determined that VASP expression levels in 26 cases of lung adenocarcinoma were significantly higher than those of 14 cases of adjacent normal lung tissues using immunohistochemistry, suggesting that VASP may serve an important function in lung adenocarcinoma progression. 
Henes et al (43) hypothesized that TNF- $\alpha$ directly regulated the biological effects of VASP by activating the transcription factor nuclear factor $\kappa \mathrm{B}$. As another nuclear transcription factor, HIF-1 $\alpha$ is involved in a complex molecular network and is a mediator of cell proliferation and cell apoptosis $(44,45)$. Haddad and Harb (46) identified that TNF- $\alpha$ promoted HIF-1 $\alpha$ translocation into the nucleus and activated HIF-1 $\alpha$ to bind downstream target genes through increasing the production of ROS in normoxic conditions in primary fetal rat alveolar epithelial type 2 cells. In addition, HIF-1-dependent expression of L1 cell adhesion molecule inhibits vascular metastasis of hypoxic breast cancer cells to the lungs (47). Our previous study identified that HIF-1 $\alpha$ mediated the repression of VASP expression in MCF-7 cells (33). HIF-1 $\alpha$ has the potential to regulate a subset of downstream genes to inhibit cell proliferation in A549 and H226 lung cancer cells.

In the present study, the expression of VASP was decreased at the mRNA and protein levels following TNF- $\alpha$ treatment in 2 lung cancer cell lines. It was identified that VASP overexpression promoted the proliferation and adhesion of A549 lung adenocarcinoma cells in vitro. However, in the A549 cells, the expression of HIF-1 $\alpha$ was increased at the mRNA and protein levels following TNF- $\alpha$ treatment, and HIF-1 $\alpha$ overexpression inhibited the proliferation and adhesion of A549 cells in vitro. Furthermore, TNF- $\alpha$ inhibited cell proliferation and adhesion following inhibition of VASP expression, whereas it promoted cell proliferation and adhesion following inhibition of HIF-1 $\alpha$ expression in A549 cells. The results of the present study provide a novel perspective for understanding the molecular mechanism underlying the antitumor effect of TNF- $\alpha$.

Furthermore, results from a luciferase assay identified HBSs in the promoter region of VASP. In addition, interference of HIF- $1 \alpha$ in the cells led to a significant increase in VASP expression at the mRNA and protein levels, and TNF- $\alpha$ is able to inhibit VASP expression at the mRNA and protein levels induced by interference of HIF-1 $\alpha$. The results of the present study revealed that decreased HIF-1 $\alpha$ expression, mediated by HIF- $1 \alpha$-siRNA, rescued the proliferation ability inhibited by TNF- $\alpha$ in 2 lung cancer cell lines. Indeed, VASP was not revealed to be the effective target gene of HIF-1 $\alpha$, undergoing no significant increase/decrease with TNF- $\alpha$ treatment in H226 cells (data not shown). Subsequently, it was identified that VASP acts downstream of HIF-1 $\alpha$, with the existence of HBSs in the VASP promoter region using luciferase analysis. It was confirmed that downregulated VASP promoter activity occurred via HIF-1 $\alpha$ in A549 cells. Furthermore, the results of the present study revealed that HIF-1 $\alpha$ mediated the antitumor effect of TNF- $\alpha$ in A549 cells.

Public databases containing clinical data indicate that lung adenocarcinoma patients exhibiting different VASP and HIF-1 $\alpha$ expression levels may have different survival outcomes (37). In the present study, an association between TNF- $\alpha / \mathrm{HIF}-1 \alpha$ and the VASP signaling pathway was identified in A549 cells; however, the underlying molecular mechanism remains unclear, and the potential use of VASP as a novel prognostic marker or a therapeutic target for lung carcinoma requires further investigation.

In summary, the results of the present study indicate that TNF- $\alpha$ inhibits the proliferation and adhesion of A549 cells, and growth of transplanted tumors in nude mice, by suppressing the expression of VASP by activating the transcriptional activity of HIF-1 $\alpha$. These data suggest that the HIF-1 $\alpha$ /VASP signaling pathway serves an important function in the regulation of TNF- $\alpha$-induced suppression of xenograft tumor growth, suggesting that our understanding of the antitumor effect of TNF- $\alpha$ requires further investigation.

\section{Acknowledgements}

Not applicable.

\section{Funding}

The present study was supported by the National Natural Science Foundation of China (grant no. 81472765), the Hubei Science Foundation (grant no. 2014CKB508), and the Laboratory and Equipment Administration of Wuhan University under the 'Open Experimentation Program of Experimental Teaching Center of Wuhan University' project.

\section{Availability of data and materials}

The datasets used and/or analyzed during the current study are available from the corresponding author on reasonable request.

\section{Authors' contributions}

WL and XC conceived and designed the experiments. YT, LW and $\mathrm{JZ}$ performed the experiments. $\mathrm{PH}, \mathrm{KS}$ and $\mathrm{ZL}$ analyzed the data. YH, LX and YM contributed reagents, materials and analysis tools. LX was responsible for cell culture, and YM was responsible for plasmid construction. YH and XC wrote the paper. All authors read and approved the manuscript and agree to be accountable for all aspects of the research in ensuring that the accuracy or integrity of any part of the work are appropriately investigated and resolved.

\section{Ethics approval and consent to participate}

The animal experiments were approved by the Experimental Ethics Committee in Basic Medical Sciences, Wuhan University (Wuhan, China).

\section{Patient consent for publication}

Not applicable.

\section{Competing interests}

The authors declare that they have no competing interests.

\section{References}

1. Torre LA, Bray F, Siegel RL, Ferlay J, Lortet-Tieulent J and Jemal A: Global cancer statistics, 2012. CA Cancer J Clin 65: 87-108, 2015.

2. Zagryazhskaya A, Gyuraszova K and Zhivotovsky B: Cell death in cancer therapy of lung adenocarcinoma. Int J Dev Biol 59: 119-129, 2015.

3. Yatabe Y, Borczuk AC and Powell CA: Do all lung adenocarcinomas follow a stepwise progression? Lung Cancer 74: 7-11, 2011. 
4. Chen ZY, Zhong WZ, Zhang XC, Su J, Yang XN, Chen ZH, Yang JJ, Zhou Q, Yan HH, An SJ, et al: EGFR mutation heterogeneity and the mixed response to EGFR tyrosine kinase inhibitors of lung adenocarcinomas. Oncologist 17: 978-985, 2012.

5. Devarakonda S, Morgensztern D and Govindan R: Genomic alterations in lung adenocarcinoma. Lancet Oncol 16: e342-e351, 2015.

6. Ben-Baruch A: The tumor-promoting flow of cells into, within and out of the tumor site: Regulation by the inflammatory axis of TNF $\alpha$ and chemokines. Cancer Microenviron 5: 151-164, 2012.

7. Wajant $\mathrm{H}$ : The role of TNF in cancer. Results Probl Cell Differ 49: 1-15, 2009.

8. Zelová $\mathrm{H}$ and Hošek J: TNF- $\alpha$ signalling and inflammation: Interactions between old acquaintances. Inflamm Res 62: 641-651, 2013

9. Wu Y and Zhou BP: TNF-alpha/NF-kappaB/Snail pathway in cancer cell migration and invasion. Br J Cancer 102: 639-644, 2010.

10. Carswell EA, Old LJ, Kassel RL, Green S, Fiore N and Williamson B: An endotoxin-induced serum factor that causes necrosis of tumors. Proc Natl Acad Sci USA 72: 3666-3670, 1975

11. Haranaka K, Satomi N and Sakurai A: Antitumor activity of tumor necrosis factor (TNF) in vitro and in vivo. Gan To Kagaku Ryoho 11: 1387-1393, 1984 (In Japanese).

12. Calzascia T, Pellegrini M, Hall H, Sabbagh L, Ono N, Elford AR, Mak TW and Ohashi PS: TNF-alpha is critical for antitumo but not antiviral $\mathrm{T}$ cell immunity in mice. J Clin Invest 117 : 3833-3845, 2007

13. Fajardo LF, Kwan HH, Kowalski J, Prionas SD and Allison AC: Dual role of tumor necrosis factor-alpha in angiogenesis. Am J Pathol 140: 539-544, 1992.

14. Weishaupt A, Gold R, Hartung T, Gaupp S, Wendel A, Brück W and Toyka KV: Role of TNF-alpha in high-dose antigen therapy in experimental autoimmune neuritis: Inhibition of TNF-alpha by neutralizing antibodies reduces T-cell apoptosis and prevents liver necrosis. J Neuropathol Exp Neurol 59: 368-376, 2000.

15. Bertazza L and Mocellin S: The dual role of tumor necrosis factor (TNF) in cancer biology. Curr Med Chem 17: 3337-3352, 2010

16. Semenza GL and Wang GL: A nuclear factor induced by hypoxia via de novo protein synthesis binds to the human erythropoietin gene enhancer at a site required for transcriptional activation. Mol Cell Biol 12: 5447-5454, 1992.

17. Wang GL, Jiang BH, Rue EA and Semenza GL: Hypoxia-inducible factor 1 is a basic-helix-loop-helix-PAS heterodimer regulated by cellular O2 tension. Proc Natl Acad Sci USA 92: 5510-5514, 1995.

18. Lee JW, Bae SH, Jeong JW, Kim SH and Kim KW: Hypoxia-inducible factor (HIF-1)alpha: Its protein stability and biological functions. Exp Mol Med 36: 1-12, 2004.

19. Weidemann A and Johnson RS: Biology of HIF-1alpha. Cell Death Differ 15: 621-627, 2008.

20. Semenza GL: Targeting HIF-1 for cancer therapy. Nat Rev Cancer 3: 721-732, 2003.

21. Schindl M, Schoppmann SF, Samonigg H, Hausmaninger H, Kwasny W, Gnant M, Jakesz R, Kubista E, Birner P and Oberhuber G; Austrian Breast and Colorectal Cancer Study Group: Overexpression of hypoxia-inducible factor 1alpha is associated with an unfavorable prognosis in lymph node-positive breast cancer. Clin Cancer Res 8: 1831-1837, 2002.

22. Chiavarina B, Whitaker-Menezes D, Migneco G, MartinezOutschoorn UE, Pavlides S, Howell A, Tanowitz HB Casimiro MC, Wang C, Pestell RG, et al: HIF1-alpha functions as a tumor promoter in cancer associated fibroblasts, and as a tumor suppressor in breast cancer cells: Autophagy drives compartment-specific oncogenesis. Cell Cycle 9: 3534-3551, 2010.

23. Fan LF, Diao LM, Chen DJ, Liu MQ, Zhu LQ, Li HG, Tang ZJ, Xia D, Liu X and Chen HL: Expression of HIF-1 alpha and its relationship to apoptosis and proliferation in lung cancer. $\mathrm{Ai}$ Zheng 21: 254-258, 2002 (In Chinese).

24. Balamurugan K: HIF-1 at the crossroads of hypoxia, inflammation, and cancer. Int J Cancer 138: 1058-1066, 2016.

25. Haffner C, Jarchau T, Reinhard M, Hoppe J, Lohmann SM and Walter U: Molecular cloning, structural analysis and functional expression of the proline-rich focal adhesion and microfilamentassociated protein VASP. EMBO J 14: 19-27, 1995.

26. Pula G and Krause M: Role of Ena/VASP proteins in homeostasis and disease. Handb Exp Pharmacol: 39-65, 2008.

27. Chen XJ, Squarr AJ, Stephan R, Chen B, Higgins TE, Barry DJ, Martin MC, Rosen MK, Bogdan S and Way M: Ena/VASP proteins cooperate with the WAVE complex to regulate the actin cytoskeleton. Dev Cell 30: 569-584, 2014
28. Zhang Y, Han G, Fan B, Zhou Y, Zhou X, Wei L and Zhang J: Green tea (-)-epigallocatechin-3-gallate down-regulates VASP expression and inhibits breast cancer cell migration and invasion by attenuating Rac1 activity. Eur J Pharmacol 606: 172-179, 2009.

29. Galler AB, García Arguinzonis MI, Baumgartner W, Kuhn M, Smolenski A, Simm A and Reinhard M: VASP-dependent regulation of actin cytoskeleton rigidity, cell adhesion, and detachment. Histochem Cell Biol 125: 457-474, 2006.

30. Knauer O, Binai NA, Carra G, Beckhaus T, Hanschmann KM, Renné T, Backert S, Karas M and Wessler S: Differential phosphoproteome profiling reveals a functional role for VASP in Helicobacter pylori-induced cytoskeleton turnover in gastric epithelial cells. Cell Microbiol 10: 2285-2296, 2008.

31. Liu K, Li L, Nisson PE, Gruber C, Jessee J and Cohen SN Reversible tumorigenesis induced by deficiency of vasodilator-stimulated phosphoprotein. Mol Cell Biol 19: 3696-3703, 1999.

32. Su K, Hu P, Wang X, Kuang C, Xiang Q, Yang F, Xiang J, Zhu S, Wei $L$ and Zhang J: Tumor suppressor berberine binds VASP to inhibit cell migration in basal-like breast cancer. Oncotarget 7: 45849-45862, 2016.

33. Su K, Tian Y, Wang J, Shi W, Luo D, Liu J, Tong Z, Wu J, Zhang J and Wei L: HIF-1 $\alpha$ acts downstream of TNF- $\alpha$ to inhibit vasodilator-stimulated phosphoprotein expression and modulates the adhesion and proliferation of breast cancer cells. DNA Cell Biol 31: 1078-1087, 2012.

34. Livak KJ and Schmittgen TD: Analysis of relative gene expression data using real-time quantitative PCR and the $2^{-\Delta \Delta C_{\mathrm{T}}}$ method. Methods 25: 402-408, 2001.

35. Wang Y, Hu PC, Gao FF, Lv JW, Xu S, Kuang CC, Wei L and Zhang JW: The protective effect of curcumin on hepatotoxicity and ultrastructural damage induced by cisplatin. Ultrastruct Pathol 38: 358-362, 2014.

36. Dertsiz L, Ozbilim G, Kayisli Y, Gokhan GA, Demircan A and Kayisli UA: Differential expression of VASP in normal lung tissue and lung adenocarcinomas. Thorax 60: 576-581, 2005.

37. Gyorffy B, Surowiak P, Budczies J and Lanczky A: Online survival analysis software to assess the prognostic value of biomarkers using transcriptomic data in non-small-cell lung cancer. PLoS One 8: e82241, 2013.

38. Wang $X$ and Adjei AA: Lung cancer and metastasis: New opportunities and challenges. Cancer Metastasis Rev 34: 169-171, 2015.

39. Baxevanis CN, Voutsas IF, Tsitsilonis OE, Tsiatas ML, Gritzapis AD and Papamichail M. Compromised anti-tumor responses in tumor necrosis factor-alpha knockout mice. Eur J Immunol 30: 1957-1966, 2000.

40. Prevost-Blondel A, Roth E, Rosenthal FM and Pircher $\mathrm{H}$ : Crucial role of TNF-alpha in CD8 T cell-mediated elimination of 3LL-A9 Lewis lung carcinoma cells in vivo. J Immunol 164: $3645-3651,2000$

41. Tandle A, Hanna E, Lorang D, Hajitou A, Moya CA, Pasqualini R, Arap W, Adem A, Starker E, Hewitt S and Libutti SK: Tumor vasculature-targeted delivery of tumor necrosis factor-alpha. Cancer 115: 128-139, 2009

42. Wang J, Zhang J, Wu J, Luo D, Su K, Shi W, Liu J, Tian Y and Wei L: MicroRNA-610 inhibits the migration and invasion of gastric cancer cells by suppressing the expression of vasodilatorstimulated phosphoprotein. Eur J Cancer 48: 1904-1913, 2012.

43. Henes J, Schmit MA, Morote-Garcia JC, Mirakaj V, Köhler D, Glover L, Eldh T, Walter U, Karhausen J, Colgan SP and Rosenberger P: Inflammation-associated repression of vasodilator-stimulated phosphoprotein (VASP) reduces alveolarcapillary barrier function during acute lung injury. FASEB J 23 4244-4255, 2009.

44. Azoitei N, Becher A, Steinestel K, Rouhi A, Diepold K, Genze F, Simmet T and Seufferlein T: PKM2 promotes tumor angiogenesis by regulating HIF-1 $\alpha$ through NF- $\kappa$ B activation. Mol Cancer 15: 3, 2016.

45. Carmeliet P, Dor Y, Herbert JM, Fukumura D, Brusselmans K, Dewerchin M, Neeman M, Bono F, Abramovitch R, Maxwell P, et al: Role of HIF-1alpha in hypoxia-mediated apoptosis, cell proliferation and tumour angiogenesis. Nature 394: 485-490, 1998 .

46. Haddad JJ and Harb HL: Cytokines and the regulation of hypoxia-inducible factor (HIF)-1alpha. Int Immunopharmacol 5: 461-483, 2005

47. Zhang H, Wong CC, WeiH, Gilkes DM,Korangath P, Chaturvedi $\mathrm{P}$, Schito L, Chen J, Krishnamachary B, Winnard PT Jr, et al: HIF-1-dependent expression of angiopoietin-like 4 and L1CAM mediates vascular metastasis of hypoxic breast cancer cells to the lungs. Oncogene 31: 1757-1770, 2012. 